\title{
CRÍTICA A LA INICIATIVA PROBATORIA JUDICIAL, A PROPÓSITO DEL PROCEDIMIENTO LABORAL CHILENO
}

\author{
Claudio Palavecino Cáceres* \\ Universidad de Chile
}

\begin{abstract}
RESUMEN: En este trabajo se critica la iniciativa probatoria judicial introducida en la jurisdicción laboral con ocasión de la reforma procesal de la Ley No 20.087. El autor parte por describir cómo la exclusión de la aportación de prueba del principio dispositivo no obedeció a una racionalidad técnica, sino política. Afirma que incluso la concepción reducida del principio dispositivo defendida por el publicismo veda al juez toda iniciativa probatoria. Cuestiona que la iniciativa probatoria judicial pueda justificarse en un interés propio del Estado y especialmente pone en duda que el proceso cumpla una función epistémica. Argumenta a favor de la tesis según la cual la prueba de oficio destruye la imparcialidad del juzgador. Concluye sosteniendo la ilegitimidad de un modelo procesal civil que intenta sobreponer fines públicos a los intereses de las partes.
\end{abstract}

Palabras clave: Jurisdicción laboral, proceso, politica, derecho, publicismo

\begin{abstract}
This paper criticizes the judicial probatory initiative introduced in the labor jurisdiction on the occasion of the process reform of Law $\mathrm{N}^{\circ} 20.087$. The author begins by describing how the exclusion of contributing the proof in the dispositive principle obeyed not to a technical but to a political rationality. He claims that even the reduced conception of such principle defended by the publicism ban the judge from any probatory intiative. He questions that the judicial probatory initiative can be justified in a self-interest of the State and especially doubts whether the process fullfills an epistemic function. Argues for the thesis under which the proof suministred by the judge himself automatically destroys the impartiality of the judge. He concludes by sustaining the idea of the illegitimacy of a model of civil process that attempts to overcome public purposes to the interests of the parties.
\end{abstract}

Key words: Labor jurisdiction, process, politics, law, publicism

\section{CRÍTICA A LOS FUNDAMENTOS PUBLICÍSTICOS DE LA INICIATIVA PROBATORIA JUDICIAL EN LOS PROCESOS CIVILES ${ }^{1}$}

\subsection{SOBRE LA MODERNA COMPRENSIÓN DEL PRINCIPIO DISPOSITIVO POR EL PUBLICISMO}

El triunfo ideológico del liberalismo sobre el Antiguo Régimen y la instauración en el plano político del moderno Estado de Derecho liberal-burgués, trajo consigo una reducción considerable de la intromisión del Estado en la sociedad civil. El nuevo principio básico de distribución ("esfera de libertad [del individuo] ilimitada en principio; facultad estatal de intervención, limitada en principio") ${ }^{2}$ tuvo sus repercusiones sobre la forma de concebir el proceso civil: el poder público, representado por el juez, debe abstenerse de cualquiera intervención hasta el momento de dictar sentencia. Las partes son dueñas tanto de los derechos sustantivos en juego como de los procesales y, por ende, tienen completa libertad de disposición sobre los mismos. Bajo esta idea, el proceso civil se configuró sobre una amplia

\footnotetext{
* Abogado. Profesor de Derecho del Trabajo y Seguridad Social y Derecho Procesal del Trabajo en la Facultad de Derecho de la Universidad de Chile. Contacto: cpalavec@derecho.uchile.cl

1 Por "procesos civiles" entiendo los de naturaleza no criminal, denominación que incluye al proceso civil en sentido estricto así como al de familia, laboral, etc.

2 SchmitT, Carl, Teoría de la Constitución. Madrid: Alianza Editorial, 2003, p. 184.
} 
dispositividad. Así, las partes pueden libremente disponer del inicio y objeto del proceso; del material probatorio y del impulso procesal.

Tal comprensión del principio dispositivo imperó hasta el fin de la Segunda Guerra Mundial. Es cierto que ya a fines del siglo XIX el proceso civil había comenzado a dar un giro en ciento ochenta grados con la Ordenanza Procesal austríaca de 1895, la cual, inspirada en las ideas del jurista Franz Klein, fortaleció las potestades formales y materiales del juez con miras al cumplimiento, ahora también en sede civil, de los fines del Estado. Pero en aquel entonces se comprendió con toda claridad que estos cambios revolucionarios eran incompatibles con el principio dispositivo ${ }^{3}$.

En un contexto histórico de innegable autoritarismo, como el del Imperio AustroHúngaro, la superación del principio dispositivo no planteaba ningún conflicto, ninguna incongruencia, ninguna disonancia, ni con el régimen político ni con la ideología que lo sustentaba. Por la misma razón, tampoco llegó a plantearse conflicto, incongruencia o disonancia alguna en los países totalitarios que, unas décadas más tarde, las primeras del siglo $\mathrm{XX}$, adoptaron la concepción social del proceso de Klein, al plasmar sus leyes procesales civiles. Muy por el contrario, resultaba totalmente funcional a estos regímenes el desplazamiento del sentido y fin del proceso, desde mecanismo para satisfacer el interés individual de las partes a instrumento para la realización de los fines del Estado.

El Código de Procedimiento Civil italiano de 1940, acaso la más trascendente concreción del ideal de proceso social, fue considerado en su tiempo como la expresión histórica del Estado fascista y corporativo. Pero, muy pronto, sus ideólogos se verían compelidos a cambiar completamente de idea. Tras la caída del fascismo, la dogmática procesal italiana se vio en la amarga disyuntiva de derogar su bienamado Codice o conciliarlo de algún modo con el sistema democrático y con el respeto a las libertades fundamentales que le es inherente. La proverbial sutileza del ingenio latino fue capaz de lograr la segunda proeza.

Como advierte, agudamente, Rorty, la coherencia apunta a la evitación de contradicciones y esta es bastante fácil de conseguir si se sigue el viejo consejo de Santo Tomás: "Si encuentras una contradicción, debes hacer una diferenciación”. La solución estaba entonces en establecer tantas diferenciaciones como hicieren falta para salir del apuro. Dicho de otro modo, para sortear la contradicción había que describir el terreno intelectual circundante de una forma nueva y de tal modo que los conceptos empleados por el contrincante parecieran irrelevantes, erróneos o sin interés ${ }^{4}$. Pues bien, no solo los filósofos distinguen cuando están en aprietos, sino también los juristas. Y esta fue, precisamente, la estratagema de los pro-

\footnotetext{
3 En un trabajo de 1914 (Grundfragen und Reform des Zivilprozess), Adolf Wach señaló sin ambages que el Reglamento de Klein contradecía la naturaleza dispositiva del proceso civil. Asimismo, en los años treinta del siglo veinte, Schönke enseñaba que la vigencia del principio dispositivo ya no era absoluta, llegando a afirmar que tal principio quedaba más quebrantado incluso que en el Derecho austriaco, en la legislación procesal civil húngara de 1911, en que la prueba de testigos podía practicarse de oficio aunque ambas partes se hubieran manifestado en contra u ordenarse la exhibición de un documento por una parte, sin que fuera preciso que ninguna de ellas lo hubiese invocado. SCHÖNKE, Adolf, Derecho procesal civil. Barcelona: Bosch, 1950, pp. 31-38. Pero incluso más recientemente, a propósito de la iniciativa probatoria del juez que introducía la Ordenanza austriaca de 1895, Fasching señala sin problemas que esta rompe definitivamente con los grilletes político-jurídicos del principio dispositivo. FASCHING, Hans Walter, "Liberalización y socialización del proceso civil”, en: Quinto Congreso Internacional de Derecho Procesal, México, 1972 (disponible online en: http://www.juridicas.unam.mx/publica/librev/rev/boletin/ cont/13/art/art2.pdf) p. 29.

4 RORTY, Richard, “Orquídeas silvestres y Trotski”. En su: Filosofía y Futuro. Barcelona: Gedisa, 2008, p. 144.
} 
cesalistas italianos: para salvar el Codice de Mussolini y neutralizar su incongruencia con el principio dispositivo, había que distinguir y así se hizo: primero entre el principio dispositivo y el principio de aportación de parte y, dentro de este segundo, entre aportación de hechos y aportación de pruebas. Ha sido mérito de Montero Aroca desvelar el modus operandi de los juristas italianos:

"Es evidente que Grandi y Calamandrei no tuvieron duda en considerar como 'factor político’ el reforzamiento de la autoridad del juez [...] pero inmediatamente después Calamandrei negaba su propia base de partida cuando, refiriéndose a la atenuación del principio dispositivo en el Codice, pretendió que el atribuir al juez poderes de iniciativa probatoria para declarar la verdad dentro del ámbito de las peticiones de las partes era 'una necesidad de orden técnico' que no tenía nada que ver con el respeto a la voluntad de las partes. Abierto ese camino, Carnacini sostuvo luego la necesidad de distinguir entre lo que se refiere al monopolio de las partes sobre el objeto del proceso, que afecta a la disposición de su interés, y lo atinente a la determinación de los materiales de hecho y de los medios para probarlo, entendiendo que este segundo aspecto afecta únicamente a la conformación del instrumento que la ley predispone para la tutela jurisdiccional. Por fin Capelletti, desde lo anterior, pasó a subdistinguir entre la introducción del material de hecho y la introducción de los medios para probarlo, afirmando también el carácter técnico de la iniciativa probatoria del juez"5.

El Estado -fascista o democrático, en adelante iba a dar exactamente igual- podía tranquilamente despojar a las partes del impulso procesal y acabar con su monopolio respecto de la aportación de las pruebas, reservándoles únicamente el monopolio sobre el inicio del proceso y la determinación de su objeto, sin afectar al principio dispositivo, ni la libertad ni la propiedad privada. Esta vuelta de tuerca fue posible gracias a la serie de distinciones que permitieron independizar el impulso procesal y la aportación de prueba del principio dispositivo. Luego de sufrir tales amputaciones, el principio dispositivo quedó en condiciones de poder cohabitar pacíficamente dentro del proceso civil con el impulso procesal y la iniciativa probatoria judiciales.

El milagro quedaba cumplido y permitió en adelante decir, con la suficiencia de un Taruffo, que el Código de Procedimiento Civil italiano no era para nada un código "fascista, salvo algunos ornamentos retóricos que -quizá inevitablemente, dado que se estaba en 1940- estaban presentes en la Relazione"6. El prodigio ya lo había anunciado Satta en 1947: ¡el prólogo era fascista, mas el Código no!?.

\footnotetext{
Montero, Juan, "Sobre el mito autoritario de la buena fe procesal". En: MONTERo, Juan (coord.), Proceso Civil e Ideología. Valencia: Tirant lo Blanch, 2006, pp. 330-331.

6 TARuffo, Michele, "Poderes probatorios de las partes y del juez en Europa", en: Ius et Praxis, vol. 12 No 2, 2006 , p. 105. Talca: Facultad de Ciencias Jurídicas y Sociales, Universidad de Talca.

7 ibid.
} 
Dominados por el mismo pathos, los procesalistas publicistas hablan hoy con desdén de la "errónea comprensión del principio dispositivo"8 y proclaman con arrogancia su "verdadera naturaleza" 9 .

Pero una vez aclarada su genealogía, estas sutiles distinciones quedan desenmascaradas como lo que son: nada más que autoengañosa sofistería. La impresión final que queda es la siguiente: si algo se salvó del naufragio del principio dispositivo -principio de demanda o justicia rogada e intangibilidad del objeto procesal por el poder público- no se debió tanto a razones técnicas como a la decisión política del fascismo de dejarlos subsistentes. Me pregunto si el ingenio latino no hubiera igualmente buscado a posteriori razones técnicas para legitimar la incoación oficiosa y la aportación de hechos por el juez, si Calamandrei y Grandi hubieran decidido incorporarlas al Codice, del mismo modo que la iniciativa probatoria judicial, como fiel reflejo del fortalecimiento del principio de autoridad del Estado.

\subsection{LA NATURALEZA JURÍDICO-PRIVADA DEL OBJETO DEL PROCESO CIVIL ELIMINA LA MÁXIMA DE LIBRE INVESTIGACIÓN}

Según afirma el publicismo, el principio dispositivo se satisface siempre que la legislación procesal reconozca que a las partes les corresponde de manera exclusiva tanto la provocación del órgano jurisdiccional como la persecución y la refutación de la pretensión. Pero la miopía publicística no consigue ver que si el poder público no puede inmiscuirse de ningún modo en el objeto del debate, entonces, deviene completamente ilógico, incongruente, que este mismo poder pueda, sin embargo, realizar por su cuenta actuaciones procesales que tengan como consecuencia el éxito o fracaso de una pretensión que, insisto, no se corresponde ni se puede corresponder jamás con su interés. Ya lo había advertido Wach cuando enseñaba que "no existe un interés oficial en que la relación jurídica litigiosa se decida de un modo determinado" 10 .

A menos que esas acciones se dirijan a un interés propio y distinto del formulado por las partes en su pretensión y resistencia. Frente a lo cual Monteleone correctamente se pregunta ¿cuál sería este distinto interés o fin que se realiza en el proceso independientemente, o en contra, del derecho subjetivo del cual aquel se desprende con el planteamiento de la demanda judicial? ${ }^{11}$.

\footnotetext{
ETXEBERRía, José, Las facultades judiciales en materia probatoria en la LEC. Valencia: Tirant lo Blanch, 2003, p. 36.

9 Hunter, Iván, "El principio dispositivo y los poderes del juez", en: Revista de Derecho de la Pontificia Universidad Católica de Valparaíso, vol. XXXV, No 2, 2010, p. 156. Valparaíso: Facultad de Derecho, Pontificia Universidad Católica de Valparaíso. En este interesante trabajo, el profesor Hunter ocupa, con innegable destreza, la táctica escolástica de las distinciones: escinde los actos procesales en dos clases: "declaraciones de voluntad" y "actos de información" y diferencia también entre hechos que integran el "acto alegatorio" y hechos que quedan fuera del mismo, sosteniendo que estos últimos pueden ser introducidos por el juez sin afectar el principio dispositivo. De este modo, da un paso más en la reducción del alcance del principio dispositivo en el proceso civil.

10 WaCh, Adolf, "El juez y las partes". En: Conferencias sobre la Ordenanza Procesal Civil Alemana. Buenos Aires: Ediciones Jurídicas Europa-América, 1958, p. 67.

11 Monteleone, Girolamo, "El actual debate sobre las 'orientaciones publicísticas' del proceso civil”. En: MonTERO, Juan (coord.), Proceso civil e ideología. Un prefacio, una sentencia, dos cartas, quince ensayos y moción de Valencia. Santiago, Chile: Editorial Metropolitana, 2008, p. 182.
} 
Para responder a esta interrogante se suele invocar los cuestionables ${ }^{12}$ postulados de Klein:

a) las controversias particulares son "males sociales (soziale Übel) relacionados con la pérdida de tiempo, dispendio de dinero, indisponibilidad infructuosa de bienes patrimoniales, fomento del odio y de ira entre las partes litigantes y de otras pasiones fatales para la convivencia de la sociedad"13, y

b) el proceso, en la medida que bloquea los bienes en espera de la decisión, incide en la economía nacional en cuanto toda "causa turba la pacífica colaboración, rompe ordenados nexos económicos, bloquea valores y los distrae de la ordinaria circulación"14.

Aceptar estas premisas -se dice- implica reconocer que el Estado tiene un interés propio y legítimo en lograr una economía de tiempos y recursos en el proceso civil. Un interés en que esos "males sociales" que son los procesos tengan una "definición rápida, poco costosa y simple" 15 . Un interés de esta naturaleza podría legitimar la atribución al juez de la dirección formal del proceso, vale decir, del control de la regularidad formal o técnica de los actos procesales y de impulsar el procedimiento para que este se desarrolle pasando de una fase a otra ${ }^{16}$, pero en ningún caso el interés público en la economía y celeridad procesales podría legitimar facultades destinadas a determinar el contenido de la sentencia, el resultado, la meta. Y es que, como decía Chiovenda, el Estado, en sede civil, no tiene interés "en el objeto del litigio", sino "en el modo en que este se desarrolla"17.

Si la prueba constituye un capítulo más en el desarrollo de la actividad de las partes en pos del juicio jurisdiccional, en cuanto se dirige a provocar el convencimiento del juzgador $^{18} \mathrm{y}$, según este lo alcance o no, la actividad probatoria terminará por definir, en la mayor parte de los juicios, el éxito o fracaso de la pretensión, no parece que se pueda reconocer una iniciativa probatoria al propio juzgador sin admitir que se le confiriere también, precisamente a través de ella, una posibilidad de intervención sobre dicho resultado distinta y anterior al acto decisorio mismo (obviamente siempre el juez favorecerá a una u otra parte al fallar la causa, la cuestión es si, además, puede realizar actuaciones distintas de la adjudicación -como decretar pruebas- que contribuyan, deliberadamente o no, a que una parte pierda y la otra gane el pleito).

Así las cosas, no me parece tan evidente que la disponibilidad de las pruebas pertenezca a la técnica del proceso y no al principio dispositivo en sentido estricto ${ }^{19}$. Antes, al

\footnotetext{
12 Para una crítica de estos postulados vid. CIPRIANI, Franco, "En el centenario del reglamento de Klein (El proceso civil entre libertad y autoridad)”. En su: Batallas por la justicia civil. Lima, Perú: Editorial Cultural Cuzco. 2003, pp. 41 y ss.

13 Sprung, citado por ibid., p. 40.

14 ibid., pp. 40-41.

15 Sprung, citado por ibid., pp. 41.

16 Montero, Juan, Los principios políticos de la nueva Ley de Enjuiciamiento Civil. Los poderes del juez y la oralidad. Valencia: Tirant lo Blanch, 2001, p. 94.

17 Citado por Cipriani, Franco, op. cit. (n. 12), p. 41.

18 Carocca, Alex, Manual de Derecho Procesal. Tomo II. Los procesos declarativos. Santiago: LexisNexis, 2003, pp. 141-151.

19 Cfr. TARuffo, Michele, Simplemente la verdad. El juez y la construcción de los hechos. Madrid: Marcial Pons, 2010, p. 200.
} 
contrario, sostengo que el objeto del proceso como límite indiscutido a la intromisión estatal no solo veda al juez la introducción de hechos al proceso, sino también la aportación de la prueba sobre esos hechos. Y no estoy diciendo nada nuevo porque lo advirtió hace un siglo Adolf Wach: "En el proceso civil, la naturaleza jurídico-privada de ese objeto elimina la 'máxima de libre investigación' [...] La sentencia es, y solo puede ser, la apreciación del material de afirmaciones y de pruebas suministrado por las partes. La prueba en el proceso civil es prueba de parte" 20 .

\subsection{INCOMPATIBILIDAD DE LOS FINES PRIVADOS Y PÚBLICOS DENTRO DEL PROCESO CIVIL}

Se insiste en que el ejercicio de la iniciativa probatoria por el juez no estaría dirigida a determinar el éxito o fracaso del interés de ninguna de las partes, sino a perseguir un fin distinto y propio del Estado, ajeno al de las partes en conflicto, que ya no tiene que ver con la economía ni la celeridad procesales y que se identificaría, en último término, con la realización del Derecho objetivo o, en una versión más sentimental -aunque mucho menos aprehensible por la inteligencia- con la obtención de una sentencia justa. Dicho de otro modo, el cometido del juez es aplicar la ley y, no solo eso, sino que además el Estado tiene interés en que la aplique correctamente o, en versión sentimental, en que el juez decida, no de cualquier modo, sino que con justicia. Se afirma que, para ser consecuente con estos fines, el Estado debe colocar al juez en posición tal de poder conocer la verdad sobre los hechos, porque solo de ese modo podrá seleccionar y aplicar correctamente las normas de derecho material relevantes o, en lenguaje habermasiano, desarrollar el discurso de aplicación o adecuación $^{21}$, y/o porque la verdad es condición necesaria de la justicia de la decisión ${ }^{22}$.

20 WACH, Adolf, "El sistema de prueba". En: Conferencias sobre la Ordenanza Procesal Civil Alemana. Buenos Aires: Ediciones Jurídicas Europa-América, 1958, pp. 225-226. En Chile, en un trabajo reciente, el profesor Nicolás Luco ha planteado la misma idea, esto es, que "otorgarle iniciativa probatoria al juez contradice el principio dispositivo", pero limitando la vigencia de este principio y su consecuencia al proceso civil en sentido estricto y descartándola "cuando existe un interés público que prevalece sobre el interés particular, como por ejemplo, en muchas áreas del derecho de familia o el derecho laboral, en que [...] la cuestión no puede quedar entregada exclusivamente al parecer de los litigantes" (LUCO, Nicolás: “¿De vuelta al sistema inquisitivo?”, En: LETURIA, Francisco (ed.) Justicia civil y comercial: Una reforma ¿cercana?, Santiago de Chile: Ediciones LYD, 2011, p. 217). Debe tenerse presente que, en materia laboral, si bien el art. $5^{\circ}$ inciso $2^{\circ} \mathrm{CT}$ establece la irrenunciabilidad de los derechos establecidos en las leyes laborales, la misma norma restringe el alcance de esta indisponibilidad a la subsistencia del contrato de trabajo, de manera que extinguido este, los derechos se tornan perfectamente disponibles por las partes. Si añadimos a esta consideración la circunstancia que, en la práctica, la abrumadora mayoría de los litigios laborales se producen con ocasión del despido, vale decir, cuando los derechos son tan disponibles como en los juicios civiles en sentido estricto, tenemos que no se puede desconocer la vigencia del principio dispositivo en el proceso laboral.

21 Según lo explica Núñez, "este discurso se refiere a la corrección de la decisión jurídica, en la cual hay que establecer si la norma prima facie aplicable es adecuada a una situación determinada, para lo que es necesario tener en cuenta todos los datos que caracterizan a esa situación, es decir, la situación de aplicación [...] el discurso de aplicación está centrado en la adecuación de las normas a la circunstancias relevantes del caso concreto (aspectos o circunstancias de hecho)". NúNEZ, Raúl, "El sistema de recursos procesales en el ámbito civil en un Estado democrático deliberativo", en: Ius et Praxis, Talca, año 14, No 1, p. 202. Talca: Facultad de Ciencias Jurídicas y Sociales, Universidad de Talca.

22 Así TARuffo, Michele, Simplemente la verdad... (n. 19). 
De este modo el proceso deviene en instrumento o método para el descubrimiento y determinación de la verdad de los hechos en los que se funda la decisión ${ }^{23}$. Para que el proceso cumpla esa función epistémica, el legislador no puede confiar la actividad probatoria exclusivamente a las partes ya que estas, mirando las cosas desde su parcialidad y en beneficio de su interés particular, pueden tomar la decisión de omitir medios de prueba relevantes. Es por eso que, en palabras de Taruffo:

"diversos legisladores procesales han advertido la necesidad de hacer que la determinación de los hechos sobre la base de las pruebas deje de ser un asunto privado de las partes y deje de depender exclusivamente de sus iniciativas y de sus elecciones tácticas. En otras palabras, esos legisladores han advertido la exigencia de dar a la actividad del juez una orientación marcadamente epistémica, confiándoles poderes necesarios para la búsqueda de la verdad" 24 .

Sobre el proceso civil como instrumento de realización del Derecho objetivo, PrietoCastro y Ferrandis afirmó, hace ya muchos años, que "se carece de razones para sostener que el derecho objetivo privado sea preferente al subjetivo y que el Estado tenga que velar por la satisfacción de este, suplantando la voluntad de los sujetos en las relaciones jurídicas" 25 . Sinceramente no creo que pueda decirse nada más sensato al respecto. Tan solo observaré que si se permite siempre a las partes la posibilidad de desistirse, allanarse o transar, que viene a ser la máxima disposición, aunque ello signifique que el Derecho objetivo quede irrealizado o triunfe la injusticia, no se comprende que, cuando cualquiera de las partes (o ambas) ejercitan un grado de disposición menor, esto es, si no prueban o prueban deficitariamente, deban ser en tal caso suplidas por el juez para que, entonces sí y solo entonces, se cumpla el Derecho objetivo y prime la justicia.

Si el proceso no mira tanto por el interés privado de las partes como por la eficacia del Derecho objetivo o, para decirlo con la misma vehemencia con que lo ha dicho en Chile Andrés Bordalí, si:

"la jurisdicción no es un servicio público puesto a disposición de los ciudadanos para que dirima sus conflictos privados [sino que l]a jurisdicción es una potestad constitucionalmente sancionada para la realización, consolidación y creación de la legalidad; es el terminal de la publicidad, esto es, la última instancia dentro del sistema estatal para defender y realizar la legalidad constitucional..."26.

\footnotetext{
23 TARUfFo, Michele, Simplemente la verdad... (n. 19), p. 155.

24 TARUfFo, Michele, Simplemente la verdad... (n. 19), p. 199. Nótese los dos prejuicios taruffianos: a) que los jueces nunca toman decisiones tácticas en el ejercicio de iniciativa probatoria, esto es, que solo actúan guiados en la negra noche de los egoísmos de las partes por la luminosa estrella de la verdad, y b) que las partes siempre buscan un fin distinto a la verdad de los hechos cuando prueban

25 Prieto-Castro y Ferrandis, Leonardo, "Informe General sobre los principios políticos y técnicos para una Ley Procesal Civil Uniforme en la Comunidad Hispánica de Naciones", en: "Trabajos y orientaciones de Derecho procesal”, Revista de Derecho privado. Madrid, 1964, p. 655.

26 Bordalí, Andrés, "Los poderes del juez civil". En: De la Oliva, Andrés y Palomo, Diego (coord.), Proceso Civil. Hacia una nueva justicia civil. Santiago: Editorial Jurídica de Chile, 2007, p. 192.
} 
Entonces, no se comprende por qué el Estado deba autorizar a las partes ya embarcadas en la nave del proceso para hundirla antes de arribar al "terminal de la publicidad", ahogando en las aguas de su egoísmo particular el interés público prevalente en la realización de la "legalidad constitucional".

En el mismo sentido, Monteleone ha resaltado la incongruencia que subsiste en reconocer un interés público y social superior a las partes y mantenerles, sin embargo, el monopolio de la incoación del proceso:

"Bajo la premisa de que el derecho de acción corresponde y se garantiza al titular de un derecho o de un interés jurídicamente relevante, para que sea declarado y tutelado frente a quien lo haya violado, y puesto que sin acción, interés y legitimación la jurisdicción civil no puede ejercitarse, ni nacer ningún proceso, ¿cómo es que este mismo derecho privado y subjetivo por el solo hecho de estar necesitado de tutela y de ser deducido en juicio pierde sus características para ser absorbido por un distinto interés público y social? Por lo menos hasta hoy no ha quedado científicamente probada la existencia de este distinto y concreto interés público y social, porque, si aquel existiera realmente, el ejercicio de la jurisdicción civil no debería nunca estar condicionado a la proposición de la demanda judicial en contradictorio, sino que debería siempre procederse de oficio en base a simple denuncia de parte" 27 .

En cuanto al interés público en la obtención de un resultado justo, existe mucho menos claridad sobre qué sea tal cosa, quiero decir, lo justo. Si uno tiene en cuenta la diversidad y disparidad de teorías sobre la justicia no es atrevido decir que los juristas contemporáneos están respecto de la justicia y lo justo en una desalentadora aporía. Por tanto, en mi opinión, todo lo más que se puede afirmar, suponiendo que se quiera mantener la retórica de la justicia en el ámbito procesal, es que la sentencia será justa en la medida que el proceso lo sea y que este lo será si en su configuración y en sus actuaciones los poderes públicos involucrados respetan ciertas garantías mínimas, a saber: la igualdad de las partes y la imparcialidad, impartialidad e independencia del adjudicador. Para otros, en cambio, esta noción de justicia es demasiado formal e insuficiente pues el juez no solo debe preocuparse por el cumplimiento de las reglas del juego sino de asegurar a las partes la "isonomía sustancial" 28 (¿igualdad material?), la cual puede llegar a exigir "determinar pruebas ex oficio, con el objetivo de elucidar los hechos; no resultando justificado que estos no sean debidamente verificados en razón de la mayor o menor suerte económica o astucia de uno de los litigantes" 29 .

Por tanto, se ha intentado justificar la iniciativa probatoria judicial "en razón de la situación débil que pueda tener una de las partes del proceso" 30 . Esta es la línea de argumentación predilecta del juslaboralismo y en tal sentido se ha afirmado que "el desequilibrio

\footnotetext{
27 MonteleOne, Girólamo, op. cit. (n. 11), p. 182.

28 Schaefer, citado por MARINONI, Luis; PÉREZ, Álvaro y NúNEZ, Raúl, Fundamentos del proceso civil. Hacia una teoría de la adjudicación. Santiago, Chile: Abeledo Perrot, 2010, p. 377.

29 ibid. (parecen seguir en esta idea a Barbosa Moreira), p. 378.

30 Bordalí, Andrés, op. cit. (n. 26), p. 197.
} 
probatorio es el drama del trabajador litigante" quien, "debe arrancar la prueba de este ambiente hostil sujeto a la presión del patrono" 31 . No se me escapa, ni pretendo obviar -como se me ha imputado en alguna ocasión- ${ }^{32}$, que el desequilibrio entre las partes de la relación de trabajo, se proyecta también en el proceso. Hago mías las palabras de Alvarado Velloso, en el sentido que:

"esa notable desigualdad real debe ser paliada. Pero no por el juez, encargado final de asegurar la igualdad jurídica de las partes procesales. Antes bien, podrá ser cuidada por defensores ad hoc, por asesores en el litigio que procedan promiscuamente con los representantes [...] de los trabajadores, por muchos y variados funcionarios [...] quienes se dediquen con exclusividad a ello. Pero insisto: nunca por el juez pues, al desnivelar la igualdad jurídica para lograr una supuesta y nunca alcanzada igualdad real, logra solo desequilibrar el fiel de la balanza de la Justicia y hacer ilegítima su sentencia" 33 .

Incluso Bordalí, quien es manifiestamente partidario de la iniciativa probatoria judicial, consigue advertir que "no parece justificable que el juez se constituya en una especie de asistente del sujeto más débil en el proceso, puesto que su deber de imparcialidad podría verse afectado" 34 .

Aun cuando no haya claridad sobre lo que signifique concretamente la idea de justicia en el contexto del proceso, sí parece haber un consenso publicístico en que justicia y verdad están muy conectadas ${ }^{35}$. A partir de esta idea se ha producido un retorno de la verdad al pro$\operatorname{ces} 0^{36}$.

\subsection{LA PRETENDIDA FUNCIÓN EPISTÉMICA DEL PROCESO}

No deja de asombrarme la tosquedad epistemológica de muchos procesalistas, ajenos según parece, a cualquier reflexión crítica sobre el conocimiento. Para la corriente procesal dominante, la formidable cuestión sobre la posibilidad de acceso a la verdad parece que quedara resuelta con otorgar iniciativa probatoria a los jueces. Cuando los procesalistas hablan ingenuamente de la verdad a uno le vienen ganas de preguntarles, como antaño hizo Poncio Pilatos, quid est veritas? ${ }^{37} \mathrm{Y}$, en efecto, conviene partir por preguntarle a los publicistas: ¿qué es la verdad?

\footnotetext{
31 Sarthou, citado por Goldstein, Eduardo y Mariezcurrena, Patricia, "Algunas reflexiones sobre los poderes de instrucción en el proceso laboral”. En: Derecho Procesal del Trabajo. Treinta estudios. Montevideo: Fundación de Cultura Universitaria, 2005 , p. 269.

32 CAAMAÑo, Eduardo, "El procedimiento de tutela: una innovación en el sentido correcto", en: La Semana Jurídica, No 335, 9-15 de abril. Santiago, Chile: LexisNexis, 2007, p. 2.

33 AlVARADO, Adolfo, Garantismo procesal contra actuación judicial de oficio. Valencia: Tirant lo Blanch, 2005, p. 261.

34 Bordalí, Andrés, op. cit. (n. 26), p. 197.

35 TARUfFo, Michele, Simplemente la verdad... (n. 19), p. 88.

36 TARUfFo, Michele, Simplemente la verdad... (n. 19), p. 89.

37 Juan, XVIII, 37.
} 
Curiosamente, Michele Taruffo, uno de los pocos procesalistas que se ha ocupado del tema con profundidad y uno de los principales defensores de la verdad en el proceso, señala que la verdad es indefinible ${ }^{38}$. Con todo, de sus trabajos se puede inferir que adscribe al concepto de verdad-correspondencia, a la vieja adaequatio rei et intellectus, conforme al cual la verdad vendría a ser una correspondencia, equivalencia o concordancia (adaequatio) entre un objeto del mundo exterior (rei) y su representación mental por el sujeto cognoscente (intellectus). Este concepto de verdad parte de dos premisas: $\left.1^{a}\right)$ que hay un conjunto objetos exteriores al sujeto cognoscente que existen con total independencia de su representación actual; en palabras simples, la realidad, y $2^{a}$ ) que la realidad es, de algún modo, cognoscible, por el ser humano.

Tanto el concepto de verdad-correspondencia como las premisas que lo sostienen han sido objeto de demoledoras críticas en las últimas décadas ${ }^{39}$, que Taruffo desprecia como mero síntoma de la "embriaguez posmoderna" de una "variopinta pandilla" de "new cynics" que descreen de la verdad, de la objetividad y del conocimiento ${ }^{40}$. Pero lo interesante es que admite, sin embargo, que la verdad:

"puede ser considerada relativa, pero no en el sentido de que resulte dependiente de las opciones individuales de los sujetos que se ocupan de ella, pues de este modo se caería en un relativismo radical inaceptable, sino más bien en el sentido de que el conocimiento de la verdad es relativo al contexto en que aquel sea realizado, al método con el que se desarrolle la investigación y a la cantidad y la calidad de las informaciones de que se disponga y sobre las cuales se funde el conocimiento" ${ }^{21}$.

Taruffo llega a afirmar que la idea de verdad estaba de algún modo presente incluso en tiempos o culturas que indagaban sobre lo desconocido mediante métodos inadecuados como la observación del vuelo de las aves o las ordalías y en tal sentido no descarta que los antiguos arúspices y los jueces medievales, entre otros, tuvieran alguna buena razón para pensar que de ese modo lograban obtener conclusiones verdaderas ${ }^{42}$ (en el sentido de reproducir correctamente objetos extramentales). Taruffo traslada esta concepción al proceso. El juez moderno cuenta con métodos e instrumentos de averiguación mucho más sofisticados que el arúspice y los jueces medievales que, sin embargo, no resultan infalibles, pero de acuerdo a este enfoque su falibilidad deviene irrelevante, porque basta con que sirvan para que el juez alcance un conocimiento relativo de la verdad. Pese a esa falibilidad se obtiene de todos modos, según Taruffo, una verdad objetiva "en la medida que no es fruto de las preferencias subjetivas e individuales del juez, o de otros sujetos, sino que se funda en razones

\footnotetext{
8 TARUfFo, Michele, Simplemente la verdad... (n. 19), p. 98.

39 Por mencionar solo una: MATURANA, Humberto: La realidad: ¿objetiva o construida? Fundamentos biológicos de la realidad, 2a edición, dos tomos, España: Editorial Anthropos, 2009.

40 TARuffo, Michele, Simplemente la verdad... (n. 19), p. 89.

41 TARUfFo, Michele, Simplemente la verdad... (n. 19), p. 99

42 TARuffo, Michele, Simplemente la verdad.... (n. 19), p. 99.
} 
objetivas que justifican el convencimiento del juez y que se derivan de datos cognoscitivos que resultan de las pruebas" 43 .

En igual sentido, Núñez enseña que "la prueba debe ser considerada como medio a través del cual el Derecho pretende determinar la verdad de las proposiciones en el marco del proceso judicial. Por otro lado, dadas las limitaciones de ese medio, la presencia del mismo no garantiza la obtención del fin (la verdad)" ${ }^{4}$. Tampoco a Núñez le inquieta esta última constatación, pues le basta con que el juez considere que los específicos medios de prueba incorporados en el proceso aportan elementos de juicio suficientes a favor de la verdad de la proposición (vale decir, de su correspondencia con los hechos del caso) y, siendo consecuente con esa estimación, la tenga por verdadera, sin importar que luego de la decisión la proposición se descubra falsa, porque a posteriori, tras la cosa juzgada, lo que importará será aquello que el juez ha tenido por verdadero y perderá relevancia aquello que es verdadero (en el supuesto de que difieran $)^{45}$.

$\mathrm{Y}$ es que incluso los más fervorosos partidarios de la función epistémica del proceso, reconocen un conjunto de límites legales y prácticos (celeridad, economía de recursos materiales y humanos, proscripción de la prueba ilícita, preclusiones, presunciones, la falibilidad de los medios de prueba, etc.) que conspiran contra la posibilidad de hallar la verdad. Los mismos autores, sin advertir ninguna contradicción, sostienen que, aunque muchas veces en el contexto del proceso no se alcance la verdad absoluta, eso nada dice contra la verdad, porque siempre la decisión será justificada por el juez mediante la afirmación (o negación) de una correspondencia entre ciertos hechos referidos por las partes y los hechos del mundo exterior que muestran las pruebas.

Pero si el proceso solo puede ofrecer un conocimiento relativo de la verdad, lo que es tenido por verdadero dadas las circunstancias, vale decir, si nunca es seguro ni necesario que la verdad se alcance, la verdad como fin del proceso se devalúa notoriamente. Lo que queda de ella no es más que un residuo evanescente, un ideal inspirador, un espejismo que el juez nunca estará obligado a alcanzar ${ }^{46}$. Bastará con su recta conciencia de obrar conforme a ese ideal, la misma convicción con que, tal vez, el adivino etrusco creía extraer la verdad de las tripas de los pájaros.

Y entonces, la afirmación (o negación) de una correspondencia entre cierto enunciado fáctico de parte y los hechos del mundo no está muy lejos de ser, también, un recurso retórico del juez para justificar su decisión ante la comunidad. Un piropo al acto de adjudicación o, como diría Humberto Maturana, un reclamo autoritario de obediencia ${ }^{47}$. Al fin y al cabo,

\footnotetext{
43 TARUfFo, Michele, Simplemente la verdad... (n. 19), p. 100.

44 NúNẼEZ, Raúl, "El sistema de recursos... (n. 21), p. 207.

45 ibid., p. 210.

46 En palabras del propio Taruffo, un "ideal regulativo, un punto de referencia hacia el que se oriente la actividad", citado por FuCHS, Andrés: Proceso, prueba y verdad, Santiago de Chile: Editorial Metropolitana, 2011, p. 62.

47 " $[\mathrm{L}] \mathrm{a}$ suposición por parte de diferentes observadores de diferentes clases de entidades independientes como fuente defintiva de validación de sus explicaciones constitutivamente los conduce a validar con su comportamiento diferentes, y por necesidad mutuamente exclusivos, universos, realidades o dominios de explicaciones objetivas. Por lo tanto, en esta línea explicativa, las explicaciones implican demanda de un acceso privilegiado a una realidad objetiva por parte del observador, $\mathrm{u}$ observadora, que explica, y en ello los observadores no tienen responsabilidad por su mutua negación en sus desacuerdos explicativos porque esta es la consecuencia de argumentos cuya validez no depende de ellos. Y es en esta línea explicativa que un reclamo de conocimiento es una demanda de obediencia."
} 
la apelación a la verdad por los jueces, termina desempeñando un papel no muy distinto que en boca de las partes y muy a tono con lo que afirman los new cynics, tan despreciados por Taruffo.

Me pregunto, cómo es que puede insistirse, una y otra vez y sin sonrojo, en la función epistémica del proceso.

\section{LA INICIATIVA PROBATORIA JUDICIAL EN LOS PROCEDIMIENTOS LABORALES}

El nuevo juez laboral viene dotado de una amplia y discrecional iniciativa probatoria. En efecto, según lo prescribe el artículo 429 del Código del Trabajo, el tribunal“[d]ecretará las pruebas que estime necesarias, aun cuando no las hayan ofrecido las partes".

Como acabamos de ver, la dogmática procesal dominante ha insistido en que a partir del principio dispositivo no se sigue inevitablemente un monopolio de las partes en relación con la aportación de prueba excluyente de la actividad probatoria judicial, porque la cuestión de la aportación quedaría fuera del contenido del principio dispositivo. La alternativa entre aportación de parte e investigación de oficiosa sería, pues, simplemente una opción técnica sobre la "que deberá discernir el legislador en base a un criterio de oportunidad o conveniencia, opción que en caso alguno significa trastrocar la fisonomía de los derechos subjetivos objeto de la tutela jurisdiccional" ${ }^{4}$. Bajo estas premisas se ha planteado que el debate en torno a la actividad probatoria del juez no debe considerar si se viola o no el principio dispositivo, sino que, la "discusión habrá de ser centrada en si esa actividad pueda violar alguno de los componentes del derecho al debido proceso de los justiciables" ${ }^{49}$. En la primera parte de este trabajo ofrecí las razones de por qué creo que el principio dispositivo no solo veda al juez la introducción de hechos al proceso, sino también la aportación de la prueba sobre esos hechos, por lo que ahora resta examinar la iniciativa probatoria judicial desde la óptica del debido proceso.

La crítica principal contra la actividad probatoria del juez dice relación con la afectación de la igualdad de las partes y la imparcialidad. Parece imposible pasar por alto que cada vez que el juez actúa para suplir las omisiones probatorias de una de las partes en conflicto, la favorece en perjuicio de la contraria, lo que conspira contra la igualdad de las partes -viga maestra del debido proceso $^{50}$ - y su corolario, la imparcialidad del juzgador.

En Chile, la igualdad de las partes en el proceso tiene sólido fundamento constitucional en el art. 19 No 3 que asegura a todas las personas la igual protección de la ley en el ejercicio de sus derechos. "En lo fundamental, es una consecuencia de la igualdad ante la ley y con ella se pretende que todos quienes deban recurrir ante cualquier autoridad, incluyendo

48 HunTER, Iván, "Potestades oficiosas del juez: ¿un síntoma de autoritarismo?”, en: La Semana Jurídica, No 347, 2-8 de julio, 2007, p. 3.

49 BORDALÍ, Andrés, op. cit. (n. 26), 190.

50 Alvarado Velloso define el debido proceso como "aquel que se adecua plenamente a la idea lógica de proceso: dos sujetos que actúan como antagonistas en pie de perfecta igualdad en el instar ante una autoridad que es un tercero en la relación litigiosa (y, como tal, imparcial, imparcial e independiente)." Alvarado, Adolfo. La garantía constitucional del proceso y el activismo judicial. ;Qué es el garantismo procesal?. Colombia: Ediciones Nueva Jurídica, 2011, p. 64. 
a los tribunales, de cualquier naturaleza, para la protección de sus derechos, se encuentren en un plano de igualdad jurídica, sin que existan privilegios o fueros especiales en razón de nacionalidad, raza, sexo, condición social o situación económica..."51. Pues bien, el otorgamiento al juez de iniciativa probatoria, cualquiera sea la motivación para su ejercicio, se traduce en la práctica en un poder interventor sobre el resultado del juicio distinto del acto de adjudicación, que en muchos casos será determinante para que una parte gane (o pierda) el juicio, pues, como ha dicho Rodríguez Urraca, "esa es la consecuencia natural de la práctica de las pruebas" 52 . La prueba de oficio genera indudablemente una desigualdad de armas no porque el actor o demandado tenga un derecho a que se falle la causa sin prueba de su contraparte, sino porque una de las partes gana con la ayuda probatoria, deliberada o no, del juez de la causa.

Como dice Carocca, "tribunal imparcial es el que carece de interés en los resultados del litigio, es decir, es completamente independiente de las partes, pues supone que este no se ve constreñido por ningún tipo de consideraciones a favorecer a una en desmedro de la otra" 53 . Coincidimos con Montero en que "el principio de imparcialidad del juez o, desde otro punto de vista, el derecho a un juez imparcial, tiene alcance general, siendo aplicable en todo tipo de procesos, incluso aunque en cada uno de ellos puedan llevar a conclusiones propias y específicas, que no podrán desvirtuar ni el principio general ni el derecho de las partes" 54 . Nuestra Constitución lo reconoce implícitamente a través del derecho a ser juzgado por el tribunal predeterminado en la ley, puesto que la imparcialidad constituye una nota esencial para configurar todo tribunal ${ }^{55}$. En cualquier caso, el llamado "Pacto de San José de Costar Rica" 56 establece en su art. $8 \mathrm{~N}^{\circ} 1$ que "toda persona tiene derecho a ser oída [...] por un juez o tribunal competente, independiente e imparcial establecido con anterioridad por la ley [...] para la determinación de sus derechos y obligaciones de orden civil, laboral, fiscal o de cualquier otro carácter", lo cual no deja mayores dudas sobre el alcance del derecho al juez imparcial en nuestro ordenamiento jurídico.

Se suele contestar a esta crítica, desde el publicismo, señalando que cuando el juez decide decretar prueba oficiosamente "no se decanta a favor o en contra de una de las partes, infringiendo de esta manera su deber de imparcialidad, pues antes de la práctica de la prueba no sabe a quién puede beneficiar o perjudicar..." 57 . El argumento es falaz. No habiéndose derogado la regla legal sobre la carga de la prueba, el juez sabe de antemano, no

51 EVANS, Enrique: Los derechos consitucionales, tomo II, 3a edición, Santiago de Chile: Editorial Jurídica de Chile, 2004, p. 140.

52 Citado por FERnÁndeZ, Raúl, Las facultades y deberes del juez en materia probatoria en el proceso laboral. Análisis crítico. Santiago, Chile: PuntoLex-Thomson Reuters, 2011, p. 159.

53 Carocca, A.: "Las garantías constitucionales del sistema procesal chileno", cit., p. 191.

54 Ibid., pp. 15-16.

55 CarocCA, Alex, op. cit. (n. 18), p. 191.

56 O más propiamente, la "Convención Americana sobre Derechos Humanos", suscrita en San José de Costa Rica el 22 de noviembre de 1969 y que entró en vigencia el 18 de julio de 1978. Chile depositó su ratificación el 21 de agosto de 1990 y fue promulgada por el Decreto No 873 de 23 de agosto de 1990 y se publicó en el Diario Oficial el 5 de enero de 1991.

57 FERnÁndeZ, Raúl, Las facultades y deberes del juez en materia probatoria en el proceso laboral. Análisis crítico. Santiago, Chile: PuntoLex-Thomson Reuters, 2011, p. 150; FuCHS, Andrés: Proceso, prueba y verdad, Santiago de Chile: Editorial Metropolitana, 2011, p. 174. Este argumento ya lo había planteado HUNTER, Iván: Las potestades probatorias del juez de familia. Santiago, Chile: LegalPublishing, 2008, p. 71. 
evidentemente, el resultado que arrojará la prueba concreta decretada, pero sí claramente a quién beneficiará y a quién perjudicará la omisión o insuficiencia probatoria respecto de determinados hechos. Si nada hace el juez frente a tal omisión o insuficiencia -pasividad legítima desde que no se le impone un deber sino una mera facultad-, la regla de la carga de la prueba resolverá por sí sola el conflicto. Y entonces surge la razonable duda, especialmente incisiva en el juicio laboral, sobre cuál razón motiva al juez en unos casos a inhibirse y en otros a salir de su pasividad y ejercer su facultad probatoria. El publicismo, bajo la cuestionable premisa de que los jueces nunca adoptan comportamientos tácticos en el ejercicio de su actividad probatoria, replica que "su único objetivo es cumplir eficazmente la función jurisdiccional encomendada por la Constitución" 58 , pero es difícil evitar la impresión de que el juez ejerce o deja de ejercer su facultad sin la plena imparcialidad que le es exigible. Y es que podría ser también que el juez salga a buscar prueba cuando sienta en su corazón que quien podría perder por insuficiencia probatoria, es quien en justicia debería ganar el pleito 59 .

Por otra parte, frente al argumento de la debilidad probatoria del trabajador, de suyo cuestionable ${ }^{60}$, cabe señalar que, al menos en Chile, las partes no pueden comparecer a juicio sin asistencia letrada y, si el trabajador no puede costearla por sí solo, la Corporación de Asistencia Judicial, organismo de carácter público, asumirá su defensa a través de alguna de sus oficinas de defensoría laboral distribuidas a través de todo el país. Pues bien, si las partes comparecen siempre con defensa letrada, no se comprende qué papel puede desempeñar la iniciativa probatoria del juez más que suplir la inepcia de los abogados, tanto más cuanto que no existe medio probatorio alguno que pueda decretar el juez que no puedan pedir también los abogados de las partes. Un firme partidario de la iniciativa probatoria judicial lo reconoce sin ambages: "Cada vez que el juez decreta una medida probatoria de oficio ayuda a la actividad probatoria deficiente de las partes, si estas no fueran en absoluto negligentes no tendrían razón de ser; los hechos serían absolutamente probados con los medios de prueba propuestos por las partes, y el juez no tendría más que aplicar el derecho sobre estos" 61 .

El sentido común indica que resultaría francamente impresentable, en cualquier proceso, ver al juez bajar de su estrado, tomar del brazo a uno de los abogados y escuchar que le susurra bondadosamente al oído: "estimado colega, olvidó usted pedir la documental, la cual es vital para el interés de su defendido en este caso. Mas no se inquiete, pues la pediré

58 FERNÁNDEZ, Raúl, Las facultades y deberes del juez en materia probatoria en el proceso laboral. Análisis crítico. Santiago, Chile: PuntoLex-Thomson Reuters, 2011, p. 150.

59 En el mismo sentido, el profesor Nicolás Luco: "Aceptemos que el juez que decide emprender esta actividad probatoria en un caso determinado y no en otro lo hace porque tiene una inclinación, una presunción más o menos fundada de que el hecho es efectivo o que la justicia no se vería satisfecha si se limitara a aplicar la carga de la prueba y dar por no probado el hecho". (LUCO, Nicolás: “¿De vuelta al sistema inquisitivo?”, En: LETURIA, Francisco (ed.) Justicia civil y comercial: Una reforma ¿cercana?, Santiago de Chile: Ediciones LYD, 2011, p. 220).

60 "Es difícil sostener que el juez está en mejor posición que las partes para determinar las pruebas que pudieren dar por comprobados los hechos alegados por ellas [... Son esas mismas partes las que mejor conocen y más cercanía tienen con los lugares, personas y actividades en que pueden ser encontradas y obtenidas dichas pruebas". (LuCO, Nicolás: "¿De vuelta al sistema inquisitivo?”, En: LETURIA, Francisco (ed.) Justicia civil y comercial: Una reforma ¿cercana?, Santiago de Chile: Ediciones LYD, 2011, p. 217).

61 FERnÁNDEZ, Raúl, Las facultades y deberes del juez en materia probatoria en el proceso laboral. Análisis crítico. Santiago, Chile: PuntoLex-Thomson Reuters, 2011, p. 126. 
yo en su lugar". Como quiera que se mire, esto es exactamente lo que ocurre cada vez que el juez llamado a dirimir un conflicto entre privados desarrolla actividad probatoria. Pero, como suele decirse, el sentido común es el menos común de los sentidos ${ }^{62}$.

En Chile se dio una larga batalla para sepultar al juez inquisidor en el proceso penal, y hubo finalmente consenso general en que el juez que acusa, investiga y juzga era una aberración intolerable ${ }^{63}$. Resulta asaz curioso que todos los argumentos que se esgrimieron entonces para transformar el proceso penal de inquisitivo en acusatorio y privar al juez penal de iniciativa probatoria, pierdan automáticamente validez, ahora, al responder la cuestión sobre la iniciativa probatoria del juez en los procesos de naturaleza no criminal.

62 Este ejemplo (que ya formulé en mi "El retorno del inquisidor. Las potestades judiciales en materia probatoria en el procedimiento laboral chileno", Revista Laboral Chilena, $\mathrm{N}^{\circ} 173$, enero, 2009, p. 79) según un joven autor chileno “...es burdo respecto de la realidad, pues no se trata y nunca se ha pretendido que el juez dotado de estas facultades reemplace a la parte, ni mucho menos a su abogado, sino que el juez dudoso de la ocurrencia de cierto hecho o no, pueda hacer todo cuanto esté dentro de sus posibilidades para conocer la verdad de lo ocurrido" (FUCHS, Andrés: Proceso, prueba y verdad, Santiago de Chile: Editorial Metropolitana, 2011, p. 174). Si no lo malentiendo, mi contradictor parte de la base que los jueces jamás desarrollan un comportamiento estratégico en el ejercicio de la iniciativa probatoria, vale decir que, en la negra noche de los egoísmos particulares, los jueces navegan guiados únicamente por la luminosa estrella de la verdad, y nunca por otros motivos externos tales como proteger a quien consideran la parte débil del conflicto, lo cual me parece -cuando menos en el contexto del proceso laboral- un postulado ingenuo y "burdo respecto de la realidad". Además de incongruente con la afirmación del propio autor en el sentido que "el proceso no es el mercado, y que por tanto no debe actuar sin intervención alguna, pues aquí no existe ninguna mano invisible que vaya a igualar el poder del imputado frente al ius puniendi del Estado, o del trabajador frente al empleador, o bien del consumidor frente al proveedor" (p. 42). Hay que insistir en que no es con la mano del juez como debe resolverse tales asimetrías.

63 Ya, Carnelutti había observado, con ocasión del proceso penal, que "la investigación es un trabajo psíquico, y a menudo físico, que puede alterar el juicio en el sentido de que el investigador puede ser arrastrado a una supervaloración de los resultados de la investigación, delineándose en él un interés por el éxito de aquella; pero tal disposición de ánimo, si bien favorece a la investigación, perjudica la valoración...”. CARneluTti, Francesco, Lecciones de Proceso Penal. Volumen II. Roma, 1949. En el mismo sentido -según informa Montero-, ha razonado el Tribunal Europeo de Derechos Humanos, con sus sentencias en los casos Piersack de 1982 y De Cubber de 1984, estimando contraria al derecho a un tribunal imparcial, tal y como aparece recogido en el art. 6.1. del Convenio Europeo para la Protección de los Derechos Humanos y las Libertades Fundamentales de 1950, la acumulación de la competencia por un mismo juez de las funciones instructora y juzgadora en el proceso penal, y, después, el Tribunal Constitucional español, en su sentencia 145/1998, de 12 de julio, que entendió incluido ese derecho a un tribunal imparcial, al que no alude la Constitución española, en el derecho a un proceso con todas las garantías, al que sí se refiere de modo expreso el artículo 24.2 de la misma, y también respecto de la regla de que quien instruye no puede juzgar. El Tribunal Constitucional español, en la sentencia citada, siguiendo los lineamientos de los fallos del Tribunal Europeo de Derechos Humanos, razona que "la actividad instructora, en cuanto para el que la lleva a cabo supone entrar en contacto directo con el acusado y con los hechos y datos que deben servir para averiguar el delito y sus posibles responsables, puede provocar en el ánimo del instructor prejuicios e impresiones a favor o en contra del acusado que influyan a la hora de sentenciar. Y aunque aquello no suceda es difícil evitar la impresión de que el juez no acomete la función de juzgar sin la plena imparcialidad que le es exigible". El profesor Nicolás Luco ha advertido cómo "la aceptación de esta realidad es lo que ha llevado a aplicar en materia procesal penal uno de los principios básicos de la reforma efectuada en Chile: aislar completamente al juez que dictará sentencia de la actividad probatoria destinada a investigar los hechos de la causa y reunir las pruebas necesarias. No se ha querido siquiera que el juez penal intervenga en la autorización de diligencias probatorias ya que ello podría comprometer su independencia, razón por la cual se ha entregado dicha función a un juez distinto, el juez de garantía". Concluye que "este celo del legislador de la reforma procesal penal debe ser aplicado igualmente en materia civil”. (LUCO, Nicolás: “¿De vuelta al sistema inquisitivo?”, En: LETURIA, Francisco (ed.) Justicia civil y comercial: Una reforma ¿cercana?, Santiago de Chile: Ediciones LYD, 2011, pp. 220-221). 


\section{REFLEXIÓN FINAL: DE LOS PELIGROS DEL PUBLICISMO PROCESAL}

\section{Como lúcidamente expone Montero:}

"Respecto de la función de la jurisdicción parece claro que hoy se mantienen sustancialmente dos posiciones: $1^{\text {a }}$ ) Hay quienes sostienen que la jurisdicción persigue la actuación del derecho objetivo mediante la aplicación de la norma al caso concreto, de modo que al Estado le corresponde asegurar la actuación del derecho objetivo en todos los supuestos en los que el mismo no sea voluntariamente observado [...] la actividad jurisdiccional se ejercita solo con el fin o, por lo menos, con el fin principal, de asegurar el respeto del derecho objetivo [...]; 2a) Otros sostenemos que la función de la jurisdicción debe centrarse en que el juez, siendo tercero e imparcial, es el último garante de los derechos que el ordenamiento jurídico reconoce al individuo, y sea cual fuere la rama del mismo que se tome en consideración" 64 .

Y bajo esta misma óptica, como dice otro autor, "el individuo ha de ser libre en la medida del interés que deba moverle a luchar por su derecho o a dejarlo ignorado o insatisfecho. Se carece de razones para sostener que el derecho objetivo privado sea preferente al subjetivo y que el Estado tenga que velar por la satisfacción de este, suplantando la voluntad de los sujetos en las relaciones jurídicas" 65 .

La primera posición defiende el proceso civil publificado o mixto. La segunda, el proceso civil dispositivo. ¿Puede todavía sostenerse que estas dos posiciones son una alternativa ideológicamente neutral, técnica, sujeta simplemente a un criterio de oportunidad o conveniencia del legislador o sería conveniente admitir que no da precisamente lo mismo uno y otro sistema?

Partiendo de la premisa que una modalidad eficiente para la solución de los conflictos debe construirse a partir de las bases mismas del sistema socio político democrático ${ }^{66}$, la alternativa legítima parece ser una sola. En efecto, en un sistema socio político que se funda en el reconocimiento y respeto de las libertades individuales, no hay disyuntiva admisible, porque mientras el sistema dispositivo se basa en la primacía de la persona sobre el Estado, el sistema inquisitivo obedece al principio inverso.

"No se trata solo de establecer quién es que puede -o debe- llevar el impulso procesal [sino de optar por] un proceso que sirva y pueda ser utilizado como medio de control social o de opresión, cual lo han pensado y puesto en práctica los regímenes totalita-

\footnotetext{
64 Montero, Juan, "Prueba y verdad en el proceso civil. Un intento de aclaración de la base ideológica de determinadas posiciones pretendidamente técnicas”. En: VV.AA., Estudios de Derecho Procesal Civil. Bases para un nuevo Código Procesal Civil. Santiago, Chile: Librotecnia, 2010, pp. 26-27.

65 Prieto-Castro y Ferrandis, Leonardo, op. cit. (n. 25), p. 655.

66 Maturana, Cristián, "La debida, pronta y eficiente solución de los conflictos laborales", en: La Semana Jurídica, No 343 , 4 al 10 junio, 2007, p. 3.
} 
rios [...] o, por el contrario, un proceso que sirve como último bastión de la libertad en la tutela de los derechos y garantías constitucionales" 67 .

La corriente de procesalistas partidarios del sistema inquisitivo se esfuerza por desmentir, contra la más prístina evidencia histórica, el origen profundamente antilibertario y liberticida de sus ideas y se manifiesta partidaria de la erradicación del lenguaje jurídico procesal de toda terminología que evoque a la Inquisición ${ }^{68}$. En cierto modo tal reacción es comprensible, puesto que, como recordaba Lord Acton ${ }^{69}$, pocos descubrimientos son tan exasperantes como los que revelan la genealogía de las ideas. Pese a los ingentes esfuerzos realizados para silenciar o absolver a los modelos procesales neoinquisitivos de su pecado de origen $^{70}$, la pesada carga de su historia todavía los determina y sus promotores se traicionan, una y otra vez, cuando afirman que el fin del proceso es trascendente a las partes y que existe, no para ellas, sino para dar primacía a la realización del Derecho objetivo o la autoafirmación del Estado y otras fórmulas similares de apenas indisimulado totalitarismo.

Se intenta desacreditar la crítica al sistema inquisitivo o mixto mediante la caricatura taruffiana que imputa a la corriente garantista la ecuación falaz "poderes de instrucción del juez = régimen autoritario". Y en tal sentido se argumenta, con notable despliegue de erudición comparatista, que muchos países incuestionablemente democráticos han implementado el proceso civil "publificado" con un juez dotado de amplios poderes formales y materiales y que nadie podría afirmar que esto los transforma en Estados autoritarios y todavía menos totalitarios $^{71}$. Afirmar esto es no entender nada. O no querer entender nada... (como estrategia erística esta caricatura pudiera resultar ingeniosa, pero no resiste mayor análisis para quien estudie con un mínimo de ecuanimidad la tesis garantista).

El árbol genealógico del proceso publificado que viene realizando pacientemente el movimiento garantista tiene por finalidad transparentar con qué fines políticos se configuró originalmente aquel sistema procesal; a qué fines perversos ha servido en determinados contextos históricos; y, lo más importante, ponernos en guardia sobre la facilidad con que, incluso

\footnotetext{
67 Alvarado, Adolfo, op. cit., (n.33), pp. 62-63.

68 Taruffo aboga por "una operación de terapia lingüística consistente en dejar de usar el término [inquisitorio], al menos con referencia al proceso civil". TARUfFo, Michelle, "Poderes probatorios de las partes y del juez en Europa". En su: La prueba. Artículos y Conferencias. Santiago, Chile: Editorial Metropolitana, 2009, p. 266.

69 LORD ACTON, “La democracia en Europa”. En su: Ensayos sobre la libertad y el poder. España: Unión Editorial, 1999, p. 295.

70 Recientemente, en Chile, se ha sostenido, siguiendo nuevamente a Taruffo, que "[e]l cambio que se verificó en relación a la naturaleza del proceso, antes concebido como algo puesto al servicio de los particulares, y después visto como medio a través del cual se expresa la autoridad del Estado, nada tuvo que ver con el surgimiento de una ideología diversa de la liberal ni mucho menos con una tentativa de inserción del proceso civil en una dimensión social, constituyendo solo el resultado de la evolución de la cultura jurídica”. MARINONI, Luiz; PÉREZ, Álvaro; y NÜÑEZ, Raúl. Fundamentos del proceso (n. 28 ), p. 15. Por el contrario, Hans Walter Fasching, luego de contrastar la ordenanza procesal civil alemana de 1877 "vinculada todavía a la ideología liberal" con la reforma austríaca de 1895 que consagraba "soluciones propias y, para aquel tiempo, revolucionarias" inspiradas en el pensamiento de Klein, afirma que "la superación del formalismo del pensamiento jurídico de la época del liberalismo mediante una 'nueva ética material de la responsabilidad', que acentúa la función social del derecho constituye el principal fundamento de la nueva estructura del proceso" y agrega que "es evidente que el incremento de la autoridad del juez es proporcional a la tendencia social del proceso civil”. FASCHING, Hans Walter, op. cit. (n. 3), pp. 26-27.

71 Así TARuffo, Michele, Simplemente la verdad... (n. 19), pp. 266 y ss.
} 
en sociedades democráticas, y aparentemente respetuosas de los derechos, puede convertirse en instrumento sutil de opresión contra los ciudadanos.

Pues, en efecto, tal opresión no solo puede provenir desde un Estado autoritario o totalitario, sino también desde los mismos contrapoderes del Estado democrático. Tan peligrosa es una justicia falta de independencia como una justicia demasiado aislada del soberano $^{72}$. Latinoamérica no es ajena a la existencia de unos jueces que pretenden imponer a la sociedad, inclusive contra las previsiones normativas del legislador democrático, su particular ideal de justicia social; su compromiso afectivo-ideológico con determinada clase social o colectivo humano históricamente victimizado o con la necesidad de acelerar el cambio social; etcétera, fenómeno que se conoce como "gobierno de los jueces", "activismo" o "decisionismo" judicial. Frente a la llamada ingenua a confiar en los jueces ${ }^{73}$, sería altamente conveniente entender, de una vez por todas, que los jueces no son moralmente superiores a las propias partes ni a sus abogados. "Quieren presentarse como el último refugio de la virtud y del desinterés en una República abandonada por sus sacerdotes" 74 , pero al igual que las partes y sus abogados se comportan, muchas veces, como hábiles patrocinadores de sus propios prejuicios y, a veces, ni siquiera demasiado hábiles ${ }^{75}$. Y es que, parafraseando nuevamente a Nietzsche, los jueces son también "humanos, demasiado humanos" y, por tanto, están sujetos a las mismas pasiones de cualquier mortal. Para evitar que los conflictos se encarnicen o se prolonguen infinitamente, las sociedades se han visto en la necesidad de darles el poder de ponerles punto final. Pero ese poder debe ser el mínimo indispensable para conseguir la paz social.

No se me escapa que "siempre es posible para el juez adoptar una actitud estratégica hacia los materiales [jurídicos], tratar de hacer que signifiquen algo distinto de lo que al principio parecía que significaban, o darles un significado que excluya otros inicialmente posibles" 76 y que "[n]o hay ninguna definición de imperio de la ley que pueda evitar que los jueces se esfuercen en esta dirección..."77. Lo mismo puede señalarse respecto de la valoración de la prueba. Pero justamente la constatación de ese inquietante poder performativo debería movernos a mantener cortas las riendas en lugar de soltarlas fatalistamente, como defiende la corriente publicista.

Así lo entendió el legislador decimonónico que tenía buenos motivos para desconfiar de la judicatura. No se olvide que una de las principales quejas contra el Antiguo Régimen fue la arbitrariedad de sus jueces y que la Revolución Francesa tuvo entre sus objetivos fundamentales precisamente terminar de una vez por todas con esa intolerable arbitrariedad judicial.

\footnotetext{
72 GARAPON, Antoine, “El poder inédito de los jueces”, en: VV.AA., Jueces y Derecho. México: Editorial Porrúa, 2008, p. 370.

73 Bravo, Pablo, "Confiar en los jueces", en: La semana jurídica, 11-24 de junio de 2008, año VIII. № 375, p. 2.

74 Garapon, Antoine, op. cit., (n.62), p. 369.

75 Vid. HunTER, Iván, "Vistos: se confirma la sentencia apelada" ¿existe el deber de motivar las sentencias en segunda instancia? (Corte de Apelaciones de Valdivia), en: Revista de Derecho, vol. 20, No 2, 2007, pp. 239-247. Valdivia, Chile: Facultad de Ciencias Jurídicas y Sociales, Universidad Austral.

76 KenNedy, Duncan, "El comportamiento estratégico en la interpretación jurídica". En: Izquierda y Derecho. Buenos Aires: Siglo XXI, 2010, p. 32

77 Ibid.
} 
Hoy, en cambio, vivimos una suerte de regresión al Ancien Régime, un "retroceso a formas premodernas de comprensión del derecho"78.

En Chile y en toda Latinoamérica la ley procesal está dejando de ser garantía y límite frente a la arbitrariedad y al abuso de poder de los jueces y, muy por el contrario, fortalece cada vez más sus prerrogativas, con lo cual multiplica exponencialmente las posibilidades de la arbitrariedad judicial.

En lugar de hallar protección en la ley, las partes y sus abogados quedan entregados a la idiosincrasia de cada juez y deben implorar o cruzar los dedos para que les toque uno prudente. Presenciamos el ejercicio de la jurisdicción desnuda, marchamos hacia la jurisdicción sin proceso.

Estos peligros intenta conjurar el garantismo procesal, por desgracia, con similar efecto que Casandra ante los troyanos. Pues como observa Garapon, en nuestros países latinos existe una inclinación cultural a los sistemas inquisitoriales: las simpatías populares no están con los abogados, sino con quien este autor llama el "pequeño juez", con el juez justiciero, al cual, paradójicamente, se le valorará tanto más cuanto transgreda la ley y se oponga a su propia jerarquía ${ }^{79}$.

Llama poderosamente la atención cómo esta comprensión vulgar de las cosas, que solo consigue ver una oposición maniquea entre el abogado forzosamente interesado y el juez forzosamente desinteresado, esforzándose por la justicia ${ }^{80}$ consigue permear sectores académicos y políticos respecto de los cuales uno esperaría un mayor grado de lucidez que en la gente ayuna de formación jurídica ${ }^{81}$.

\section{BIBLIOGRAFÍA}

AlVARADO, Adolfo. Garantismo procesal contra actuación judicial de oficio. Valencia: Tirant lo Blanch, 2005.

ALVARADO, Adolfo. "La imparcialidad judicial y el sistema inquisitivo de juzgamiento". En: MonTERO, Juan (coord.). Proceso Civil e Ideología. Valencia: Tirant lo Blanch, 2006, pp. 217-247.

ALVARADO, Adolfo. La garantía constitucional del proceso y el activismo judicial. ¿Qué es el garantismo procesal? Colombia: Ediciones Nueva Jurídica, 2011.

ATRIA, Fernando. "Jurisdicción e independencia judicial: el poder judicial como poder nulo", en: Revista de Estudios de la Justicia No 5, 2004. Santiago, Chile: Facultad de Derecho, Universidad de Chile.

Bordalí, Andrés. "Los poderes del juez civil”. En: De la Oliva, Andrés y Palomo, Diego (coord.), Proceso Civil. Hacia una nueva justicia civil. Santiago: Editorial Jurídica de Chile, 2007.

\footnotetext{
78 Atria, Fernando, "Jurisdicción e independencia Judicial: el poder judicial como poder nulo", en: Revista de Estudios de la Justicia No 5, 2004, p. 140. Santiago, Chile: Facultad de Derecho, Universidad de Chile.

79 GARAPON, Antoine, op. cit., (n. 62), p. 385.

80 Ibid.

81 Leía yo recientemente en la prensa que el ministro de justicia declaró que nuestro procedimiento civil "surgió [en] el siglo XIX, se promulgó a principios del siglo XX y no está a la altura del siglo XXI”. Se me vino de inmediato a la mente aquella historia según la cual, Juan Hus, ya quemándose en la hoguera y advirtiendo cómo una viejecilla, movida por su celo religioso, arrojaba más leña a las llamas, exclamó al Cielo: O sancta simplicitas! El eslogan del ministro se dice fácil y se repite a menudo. Es la leña que alimenta el fuego en que hoy se quema, poco a poco, la libertad. Pues, como muy bien saben sus enemigos, una mentira repetida mil veces, tarde o temprano, termina por convertirse en verdad. Entrevista al ministro de Justicia Felipe Bulnes: "Gobierno ajustará institucionalidad jurídica a estándares del siglo XXI", en: Diario Estrategia, lunes 25 de octubre de 2010, pp. 28-29
} 
Bravo, Pablo. “Confiar en los jueces”, en: La semana jurídica, 11-24 de junio de 2008, año VIII. No 375.

CAAMAÑo, Eduardo. "El procedimiento de tutela: una innovación en el sentido correcto", en: La Semana Jurídica, No 335, 9-15 de abril. Santiago, Chile: LexisNexis, 2007.

CarnelutTi, Francesco. Lecciones de Proceso Penal. Volumen II. Roma, 1949.

CArocca, Alex. Manual de Derecho Procesal. Tomo II. Los procesos declarativos. Santiago: LexisNexis, 2003.

CAroccA, Alex. "Las garantías constitucionales del sistema procesal chileno", en: Ius et Praxis, año 3, No 2. Talca: Facultad de Ciencias Jurídicas y Sociales, Universidad de Talca.

CipRIANI, Franco. "En el centenario del reglamento de Klein (El proceso civil entre libertad y autoridad)”. En su: Batallas por la justicia civil. Lima, Perú: Editorial Cultural Cuzco. 2003.

Cipriani, Franco. "El autoritarismo procesal (y las pruebas documentales)”, en: Ius et Praxis, vol. 13, n², pp. 45-55. Talca: Facultad de Ciencias Jurídicas y Sociales, Universidad de Talca.

ETXEBERRÍA, José. Las facultades judiciales en materia probatoria en la LEC. Valencia: Tirant lo Blanch, 2003.

EVANS, Enrique. Los derechos consitucionales, $-3^{\text {a }}$ edición-, tomo II. Santiago, Chile: Editorial Jurídica de Chile, 2004.

FASCHING, Hans Walter. "Liberalización y socialización del proceso civil”, en: Quinto Congreso Internacional de Derecho Procesal, México, 1972, (disponible online en: http://www.juridicas.unam.mx/publica/librev/ rev/boletin/cont/13/art/art2.pdf).

FERNÁNDEZ, Raúl. Las facultades y deberes del juez en materia probatoria en el proceso laboral. Análisis crítico. Santiago, Chile: PuntoLex-Thomson Reuters, 2011.

FUCHS, Andrés. Proceso, prueba y verdad. Santiago, Chile: Editorial Metropolitana, 2011.

GARAPON, Antoine. "El poder inédito de los jueces", en: VV.AA., Jueces y Derecho. México: Editorial Porrúa, 2008.

Goldstein, Eduardo y MARIEZCURREnA, Patricia. "Algunas reflexiones sobre los poderes de instrucción en el proceso laboral”. En: Derecho Procesal del Trabajo. Treinta estudios. Montevideo: Fundación de Cultura Universitaria, 2005.

Hayek, Ashton, Hacker, De Jouvenel, Hutt. El capitalismo y los historiadores. Madrid: Unión Editorial, 1974.

HAYEK, Friedrich. La fatal arrogancia. Los errores del socialismo. Madrid: Unión Editorial, 1990.

HAYEK, Friedrich. "El espejismo de la justicia social”. En su: Derecho, Legislación y Libertad. Madrid: Unión Editorial, 2006.

HUNTER, Iván. “Potestades oficiosas del juez: ¿un síntoma de autoritarismo?”, en: La Semana Jurídica, No 347, 2-8 de julio, 2007.

HunTer, Iván. "Poderes del juez civil: Algunas consideraciones a propósito del juez de familia”, en: Revista de Derecho, vol. 20, No 1, 2007, pp. 205-229. Valdivia, Chile: Facultad de Ciencias Jurídicas y Sociales, Universidad Austral.

HUNTER, Iván. "Vistos: se confirma la sentencia apelada” ¿existe el deber de motivar las sentencias en segunda instancia? (Corte de Apelaciones de Valdivia), en: Revista de Derecho, vol. 20, No 2, 2007. Valdivia, Chile: Facultad de Ciencias Jurídicas y Sociales, Universidad Austral.

HUNTER, Iván. Las potestades probatorias del juez de familia. Santiago, Chile: LegalPublishing, 2008.

HUNTER, Iván. "El principio dispositivo y los poderes del juez", en: Revista de Derecho de la Pontificia Universidad Católica de Valparaíso, vol. XXXV No 2, 2010. Valparaíso: Facultad de Derecho, Pontificia Universidad Católica de Valparaíso.

JEQUIER, E. "La obtención ilícita de la fuente de la prueba en el proceso civil, análisis comparativo del ordenamiento jurídico español y chileno", en: Revista Chilena de Derecho, vol. 34 N 3, 2007, pp. 457-494. 
KENNEDY, Duncan. “El comportamiento estratégico en la interpretación jurídica”. En: Izquierda y Derecho. Buenos Aires: Siglo XXI, 2010.

LORD ACTON. "La democracia en Europa”. En su: Ensayos sobre la libertad y el poder. España: Unión Editorial, 1999.

LUCO, Nicolás. “¿De vuelta al sistema inquisitivo?”. En: LETURIA, Francisco (ed.). Justicia civil y comercial: Una reforma ¿cercana? Santiago, Chile: Ediciones LYD, 2011, pp. 207-229.

MARINONI, Luis; PÉREZ, Álvaro y NúÑEZ, Raúl. Fundamentos del proceso civil. Hacia una teoría de la adjudicación. Santiago, Chile: Abeledo Perrot, 2010.

Maturana, Cristián. "La debida, pronta y eficiente solución de los conflictos laborales", en: La Semana Jurídica, No 343, 4 al 10 junio, 2007.

Maturana, Humberto. La realidad: ¿objetiva o construida? Fundamentos biológicos de la realidad -2a edición-. Dos tomos. España: Editorial Anthropos, 2009.

Monteleone, Girolamo. "El actual debate sobre las 'orientaciones publicísticas' del proceso civil”. En: MONTERO, Juan (coord.), Proceso civil e ideología. Un prefacio, una sentencia, dos cartas, quince ensayos y moción de Valencia. Santiago, Chile: Editorial Metropolitana, 2008.

Montero, Juan. Los principios políticos de la nueva Ley de Enjuiciamiento Civil. Los poderes del juez y la oralidad. Valencia: Tirant lo Blanch, 2001.

Montero, Juan. "Sobre el mito autoritario de la buena fe procesal”. En: MonTero, Juan (coord.), Proceso Civil e Ideología. Valencia: Tirant lo Blanch, 2006.

Montero, Juan. "Sobre el mito autoritario de la buena fe procesal". En: Montero, Juan (coord.), Proceso Civil e Ideología. Valencia: Tirant lo Blanch, 2006.

Montero, Juan (coord.), Proceso Civil e Ideología. Valencia: Tirant lo Blanch, 2006.

MonTero, Juan. "Prueba y verdad en el proceso civil. Un intento de aclaración de la base ideológica de determinadas posiciones pretendidamente técnicas”. En: VV.AA., Estudios de Derecho Procesal Civil. Bases para un nuevo Código Procesal Civil. Santiago, Chile: Librotecnia, 2010.

NúNEZZ, Raúl. "El sistema de recursos procesales en el ámbito civil en un Estado democrático deliberativo", en: Ius et Praxis, Talca, año 14, No 1. Talca: Facultad de Ciencias Jurídicas y Sociales, Universidad de Talca.

PAlaVECINO, Claudio. "El retorno del inquisidor. Las potestades judiciales en materia probatoria en el procedimiento laboral chileno", en: Revista Laboral Chilena, N 173 , enero, 2009, pp. 73-85

PAlaVECINO, Claudio. "Sistemas procesales e ideología. Reflexiones a propósito de la reforma procesal laboral chilena”, en: Revista Dogmática Procesal Latinoamericana. Temas de Derecho procesal, Instituto Sudamericano de Dogmática Procesal, Capítulo Perú, N 4, octubre 2010, pp. 15-28.

PRIETO-CASTRO y FERRANDis, Leonardo. “Informe General sobre los principios políticos y técnicos para una Ley Procesal Civil Uniforme en la Comunidad Hispánica de Naciones”, en: "Trabajos y orientaciones de Derecho procesal”, Revista de Derecho privado. Madrid, 1964.

RACCIATI, O. "Trascendencia procesal de los principios del derecho del trabajo", en: Revista Derecho Laboral, No 196, Montevideo, octubre-diciembre, 1999, pp. 836 y ss.

RaCCiATi, O. "Los principios del derecho laboral en el derecho procesal del trabajo". En: Derecho Procesal del Trabajo. Treinta estudios. Montevideo: Fundación de Cultura Universitaria, 2005, pp. 17-33.

RORTY, Richard. “Orquídeas silvestres y Trotski”. En su: Filosofía y Futuro. Barcelona: Gedisa, 2008.

SCHMitT, Carl. Teoría de la Constitución. Madrid: Alianza Editorial, 2003.

SCHÖNKE, Adolf. Derecho procesal civil. Barcelona: Bosch, 1950.

SOTO Kloss, Eduardo. "La potestad sancionadora de la administración, ¿̇se adecua a la Constitución”, en: VV.AA. Sanciones administrativas y derechos fundamentales: regulación y nuevo intervencionismo. Santiago: Academia de Derecho Universidad Santo Tomás, 2005, pp. 29-49. 
TARUffo, Michele. "Poderes probatorios de las partes y del juez en Europa”, en: Ius et Praxis, vol. 12 No 2, 2006. Talca: Facultad de Ciencias Jurídicas y Sociales, Universidad de Talca.

TARUfFo, Michelle. "Poderes probatorios de las partes y del juez en Europa”. En su: La prueba. Artículos y Conferencias. Santiago, Chile: Editorial Metropolitana, 2009.

TARUffo, Michele. Simplemente la verdad. El juez y la construcción de los hechos. Madrid: Marcial Pons, 2010.

WACH, Adolf. "El juez y las partes”. En: Conferencias sobre la Ordenanza Procesal Civil Alemana. Buenos Aires: Ediciones Jurídicas Europa-América, 1958.

WACH, Adolf. “El sistema de prueba”. En: Conferencias sobre la Ordenanza Procesal Civil Alemana. Buenos Aires: Ediciones Jurídicas Europa-América, 1958.

WALTER, Rodolfo y LANATA, Gabriela. Régimen legal del nuevo proceso laboral chileno. Estudio de las modificaciones introducidas por las leyes $N^{\circ}$ 20.022, 20.023 y 20.087 -2a edición-. Santiago: LexisNexis, 2007. 